\title{
BROODSTOCK CONDITIONING FOR THE TROPICAL ABALONE (Haliotis asinina) UNDER DIFFERENT COMBINATION OF PHOTOPERIOD AND WATER TEMPERATURE
}

\author{
D. E. Djoko Setyono*)
}

\begin{abstract}
The main purpose of this study is to understand the influence of external parameters, i.e., photoperiod and water temperature, on gonadal maturation of tropical abalone (Haliotis asinina) in southern Lombok waters, NTB. The abalones weres conditioned under different combinations of photoperiod and temperatures, i.e., 0 hrs dark and $24 \mathrm{hr}$ light (OD:24L), $12 \mathrm{hrs}$ dark and $12 \mathrm{hrs}$ light (12D:12L), and $24 \mathrm{hr}$ dark and 0 hrs light (24D:OL) for photoperiod and 27,29 , and $31^{\circ} \mathrm{C}$ for water temperature. The results showed that water temperature was not likely to be the main environmental factor controlling gonadal development of $H$. asinina in Lombok waters. However, photoperiod was proven to have some effect on the rates of gonad maturation in females. Reducing the length of photoperiod increased the rates of female gonad maturation. Conditioning the male was not crucial as most males finally naturally mature, even some of the males spawned spontaneously in the tanks under any of the photoperiod and water temperature regimes studied.
\end{abstract}

KEYWORDS: conditioning, abalone, Haliotis asinina, photoperiod, water temperature

\section{INTRODUCTION}

In temperate abalone, gonad development occurs rapidly during winter, with oocytes shifting from previtellogenic into vitellogenic stages and maturening in the spring, and spawning generally occurring during the summer season (Shepherd \& Laws 1974; Grange 1976; Ikenoue \& Kafuku 1992; Saout et al., 1999). Temperate abalone typically show a resting phase in the winter, when gametogenic activity is suspended (Webber 1977). However, there are exceptions to this generalisation with breeding periodicity varying according to geographic and environmental conditions (lkenoue \& Kafuku 1992).

Gametogenic activity of haliotids is believed to be controlled by a long-term endogenous rhythm, with an annual or lunar phase, and an additional zeitgeber (time giver) from the exogenous environment (Hahn 1989a). It is believed that water temperature, water quality, photoperiod, tides, exposure to wave action, exposure to air temperature, salinity, food supply, and nutrition are factors that affect gonad development, and the breeding cycle of gastropods (Kinne 1970; Webber 1977; Tutschulte \& Connell 1981; Runham 1988; Hahn 1989a, 1989c). Apart from acting as a stimulus for spawning, changes in temperature may also play an important role in gonad maturation, as well as in regulating reproductive cycles (Uki \& Kikuchi 1984; Hahn 1989a, 1989b, 1989c; Well \& Keesing 1989; Kabir 2001).

Some studies have shown that photoperiod plays an important role in regulating the reproductive cycle of several gastropods. For example, the reproductive cycle of the pulmonate snail, Lymnaea stagnalis (Bohlken \& Joose 1982; Dogterom et al., 1983;
Bohlken et al., 1987), L. peregra (Lundelius \& Freeman 1986), the nudibranch, Aplysia california (Wayne \& Block 1992), and the slug, Limax maximus (McCrone \& Sokolove 1979) are mediated by photoperiod. Lundelius \& Freeman (1986) confirmed that a photoperiod signal is received by a photoreceptor located in the cerebral ganglia. The signal then activates the neurosecretory cells within the cerebral ganglia to release hormones that stimulate the development of the reproductive organ.

Successful broodstock conditioning to produce mature animals on a predictable basis is the key to successful tropical abalone hatcheries. The main purpose of this study is to understand the influence of the two main external parameters (i.e., photoperiod and sea temperature) on gonad maturation of $H$. asinina in southern Lombok waters, NTB. This study will give a better practical knowledge about broodstock conditioning under laboratory conditions using the parameters singly or in combination.

\section{MATERIALS AND METHODS}

\section{Visual Gonadal Bulk (VGB)}

Visual and subjective inspection were done to determine 'gonadal stage'. Gonadal stage was determined without sacrificing the animals. Each abalone was held horizontally upside down and the gonad and digestive gland were viewed by looking straight across the edge of the shell, and/or by pushing gently the foot down (Setyono, 2003). Determination and classification of visual gonadal bulk (VGB) have been confirmed by histological analysis (Setyono, 2003).

\footnotetext{
Division of Marine Resources, Research Centre for Oceanography, Indonesian Institute for Sciences, Jakarta
} 
Subjective inspection was done by two people to determine the percentage of 'visual gonadal bulk' compared to the entire conical appendage. Gonads were classified into 4 stages, from 0 to 3 . Stage " 0 " is recovery, " 1 " is maturing, " 2 " is mature and " 3 " is partly spawned or spent (Table 1).

\section{Condition Factor}

An increase in muscle weight is indicative of good consumption or feeding rates (Barkai \& Griffiths, 1988; Fermin, 2002). Therefore, in this study, condition factor is used to compare the health of the broodstock at the beginning and the end of the conditioning period. Condition factor (CF) was determined as follows (Chua \& Teng 1978):

$$
C F=\left(W: L^{3}\right) \times 1000
$$

Where:

$$
\begin{aligned}
& W=\text { body weight }(\mathrm{g}) \text { and } \\
& \mathrm{L}=\text { shell length }(\mathrm{mm}) .
\end{aligned}
$$

\section{Broodstock}

Abalones used in this study were collected from coastal areas of southern Lombok, eastern Indonesia. Abalone having size $\geq 50.0 \mathrm{~mm} \mathrm{SL}$ were chosen and used for this study. Setyono (2003) found that male and female $H$. asinina become sexually mature at a size (shell length) of $45 \mathrm{~mm}$ and $50 \mathrm{~mm}$, respectively. After field collection the abalone were brought to the laboratory and placed in the holding tanks filled with fresh static seawater at an ambient temperature $\left(27^{\circ} \mathrm{C}\right)$ and aerated. Gracilaria spp. was given at ad libitum during the first two weeks of conditioning to enable the abalone to adapt to their new environment before treatments were applied.

Abalones in recovery stage (stage " 0 " of VGB) were chosen randomly from the holding tanks for this study. The animals were then sexed and labelled with a numbered plastic tag glued onto the outside of the shell. The labels consisted of plastic strips from a diallabeller. Abalone possess a single gonad. Testis and ovary are easily distinguished. The gonad are easily viewed by pushing gently the foot down. The testis appears cream coloured and the ovary has a greenish coloured (Setyono 2003). Ninety pairs (90 males and 90 females) of recovery broodstock were selected for this study.

After tagging, each animal was put on a dry towel to remove any water from around the body and shell, and then measured and weighed to the nearest of 0.1 $\mathrm{mm}$ shell length and $0.1 \mathrm{~g}$ body weight, respectively.

\section{Experimental condition}

Nine black cylindrical plastic tanks were used to hold the broodstock of $H$. asinina. Each tank was filled with approximately 30 litres of seawater and aerated Ten pairs (10 males and 10 females) of randomly chosen tagged abalone were put into each tank.

The experimental design is shown in Table 2. A fluorescent tube (20 watts) was suspended about 20 $\mathrm{cm}$ above the water surface of each tank and set on for $24 \mathrm{hrs}$ in the first treatment and set on for $12 \mathrm{hrs}$ and off for $12 \mathrm{hrs}$ in the second reatment. The third treatment was held under $24 \mathrm{hrs}$ darkness. Two water heaters were placed in each tank to maintain the water temperature at the set level $\left(27,29\right.$, and $\left.31^{\circ} \mathrm{C}\right)$. Pseudoreplication occurred in this study as replicates animals were in the same tank due to limitation of laboratory facilities

Abalones were fed ad libitum with Gracilaria spp Each morning the water in the tanks was siphoned out totally to remove waste (faecal and excess food) without removing the animals. This cleaning activity

\begin{tabular}{|c|c|c|c|}
\hline $\begin{array}{l}\text { Gonad } \\
\text { stage }\end{array}$ & $\begin{array}{l}\text { Maturity } \\
\text { stage }\end{array}$ & $\begin{array}{l}\text { Visual gonad } \\
\text { bulk }(\%)\end{array}$ & Description \\
\hline 0 & Recovery & $<25$ & $\begin{array}{l}\text { Gonad is visible at the apex of the digestive gland, testes are } \\
\text { creamy white and ovaries are light green in colour. }\end{array}$ \\
\hline 1 & Maturing & $25-49$ & $\begin{array}{l}\text { Gonad has grown and envelopes about } 25-49 \% \text { of the entire } \\
\text { digestive gland. }\end{array}$ \\
\hline 2 & Mature & $>49$ & $\begin{array}{l}\text { Gonad is fully grown, enveloping }>49 \% \text { of entire digestive } \\
\text { gland. Testes are yellowish and ovaries are greenish in } \\
\text { colour. In fully mature animals, gonad enveloping }>75 \% \text { of } \\
\text { entire digestive gland, becomes bulky and can often be seen } \\
\text { without lifting the animals. }\end{array}$ \\
\hline 3 & $\begin{array}{l}\text { Partly } \\
\text { spawned or } \\
\text { spent }\end{array}$ & $<50$ & $\begin{array}{l}\text { Animals have released gametes, the gonad is flaccid and } \\
\text { pale in colour. It is difficult to differentiate between the } \\
\text { recovery and partly spawned or spent gonad stages based } \\
\text { only on the size or percentage area of the gonad. However, } \\
\text { in partly spawned or spent gonad the size is reduced } \\
\text { significantly and the gonad is flaccid and pale in colour. }\end{array}$ \\
\hline
\end{tabular}
took about 15 minutes per tank, and exposed the

Table 1. Classification of gonadal maturation for conditioned Haliotis asinina 
Design of broodstock conditioning experiment for $H$. asinina under different photoperiods $(D=$ dark; $L=$ light; $0,12,24=$ hours $)$ and water temperature regimes $\left({ }^{\circ} \mathrm{C}\right)$

\begin{tabular}{lccc}
\hline Water & \multicolumn{3}{c}{ Photoperiod } \\
\cline { 2 - 4 } temperature & O D : 24 L & 12 D : 12 L & 24 0 L \\
\cline { 2 - 4 } & 27 & 27 & 27 \\
29 & 29 & 29 & 31 \\
\hline 31 & 31 & 29 \\
\hline
\end{tabular}

animals to the air for about 5-10 minutes each day. Fresh seawater at room temperature was poured into the tank slowly and food was then added. It took about 30 minutes to heat up the water to the set level. Water was also changed directly after animals released gametes, usually in the early evening or late morning. Spent animals were recorded at that time. All animals were examined over 11 weeks of conditioning.

\section{Statistical analysis}

Analysis of variance was performed to test for significant differences between the mean values of VGB growth for photoperiod and water temperature treatments. The VGB data were first tested for normality. The LSD Post Hoc test was used to identify significant differences between treatments. A chisquare test was performed to test the null hypothesis (Ho) that the frequencies of spontaneous spawnings between males and females under the conditioning period was not different. All test were performed using the software package DataDesk 4.1 (Data Description, Inc. Ithaca, N. Y.).

\section{RESULTS}

The results of the final observations after 11 weeks of broodstock conditioning are presented in Tables 3 for males and Table 4 for females. In these tables, standard deviations were presented rather than standard error of the mean to avoid errors in the interpretation of dependent rather than independent sample size of pseudoreplicated data (Hurlbert 1984).

Visual gonadal bulk growth was significantly larger in the males than in the females $(P \leq 0.0001)$. Visual gonadal bulk growth was not significantly different between temperature regimes $(P=0.8562)$, but it was significantly different between photoperiod regimes $(P$ $=0.0253$ ).

In males, mean values of percentage of VGB growth were not significantly different between broodstock conditioned at different photoperiod and temperature regimes $(P>0.05)$. However, visual inspection revealed that most of the males were in the stages of maturing or mature after 11 weeks of conditioning under all photoperiod and temperature regimes.
Females conditioned at 24D:OL have VGB growth which were significantly larger than animals which conditioned under 12D:12L $(P=0.0414)$ and $0 D: 24 L$ $(P=0.0004)$. Some animals under $24 \mathrm{hrs}$ dark at $31^{\circ} \mathrm{C}$ became fully mature with visual gonadal bulk $>75 \%$.

Condition factors were significantly different between males and females $(P<0.0014)$. However, condition factors were not really different between times in the same sex $(P=0.4320)$, except for females conditioned under OD:24L at $27^{\circ} \mathrm{C}$ (Data not shown)

Some males and females had released gametes spontaneously in the conditioning tanks (Table 5). Animals released gametes within 2-4 days before and/or after the new moon and/or full moon periods. The number of males and females that released gametes into the conditioning tanks was not significantly different under OD:24L and 24D:OL $(P>$ 0.05 ). However, there was significantly more males than females spawned under the 12D:12L ( $P<$ 0.0262).

\section{DISCUSSION}

Water temperature is believed to be one of the main exogenous factor regulating reproductive cycles in marine invertebrates (Underwood, 1974; Lasiak, 1987; Hahn, 1989a). However, the present study shows that water temperature was likely not the main environmental factor that controlled gonadal development of $H$. asinina in Lombok waters. This conclusion is supported by the record of natural sea temperature, which was relatively constant during the whole year, ranging between $28.5-29.5^{\circ} \mathrm{C}$ (Setyono 2003).

In the laboratory, simply controlling the water temperature and feeding level is not always successful in inducing gonad maturation in all species of abalone (Hahn 1989b). In the present study, maturation of the testes of tropical abalone $(H$. asinina) was simple as most of the males matured and some spawned spontaneously in the tanks under all treatments (Table 5). The number of males that released gametes spontaneously in the spawning tanks was significantly greater than the females $(P=$ 0.0262 ) at $12 \mathrm{D}: 12 \mathrm{~L}$. This might occur because males 


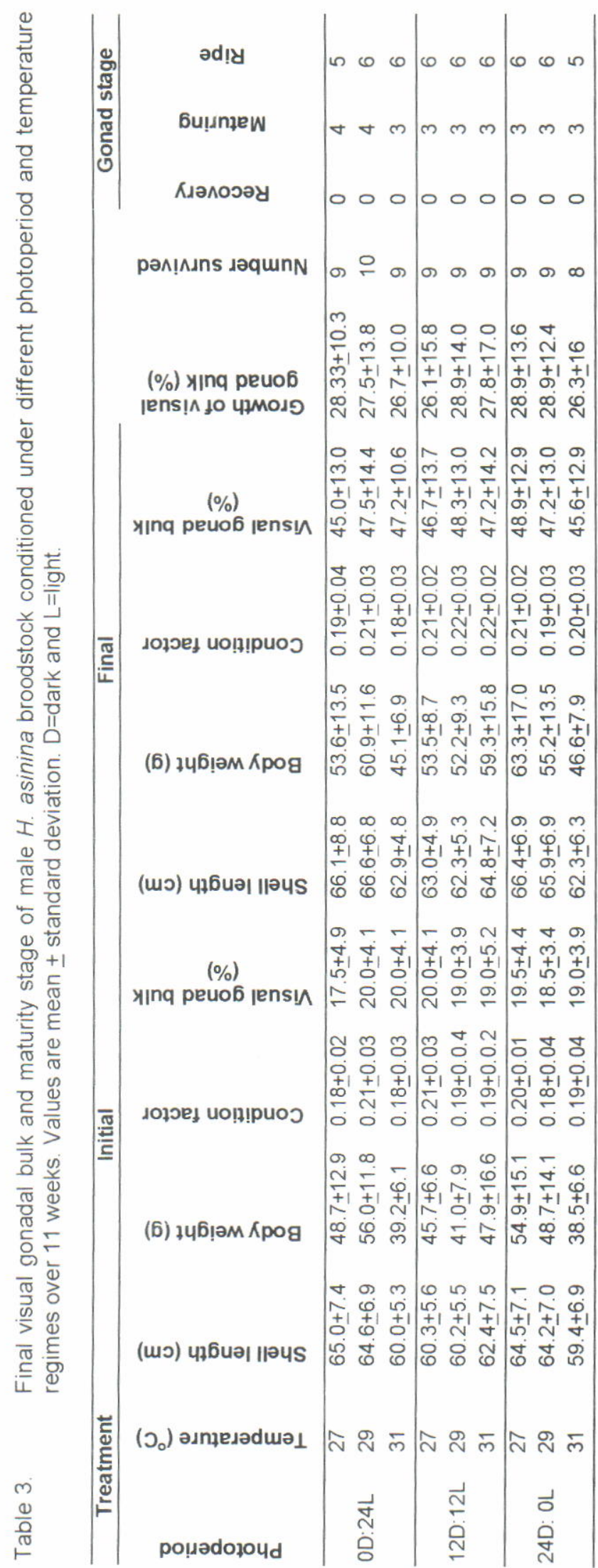




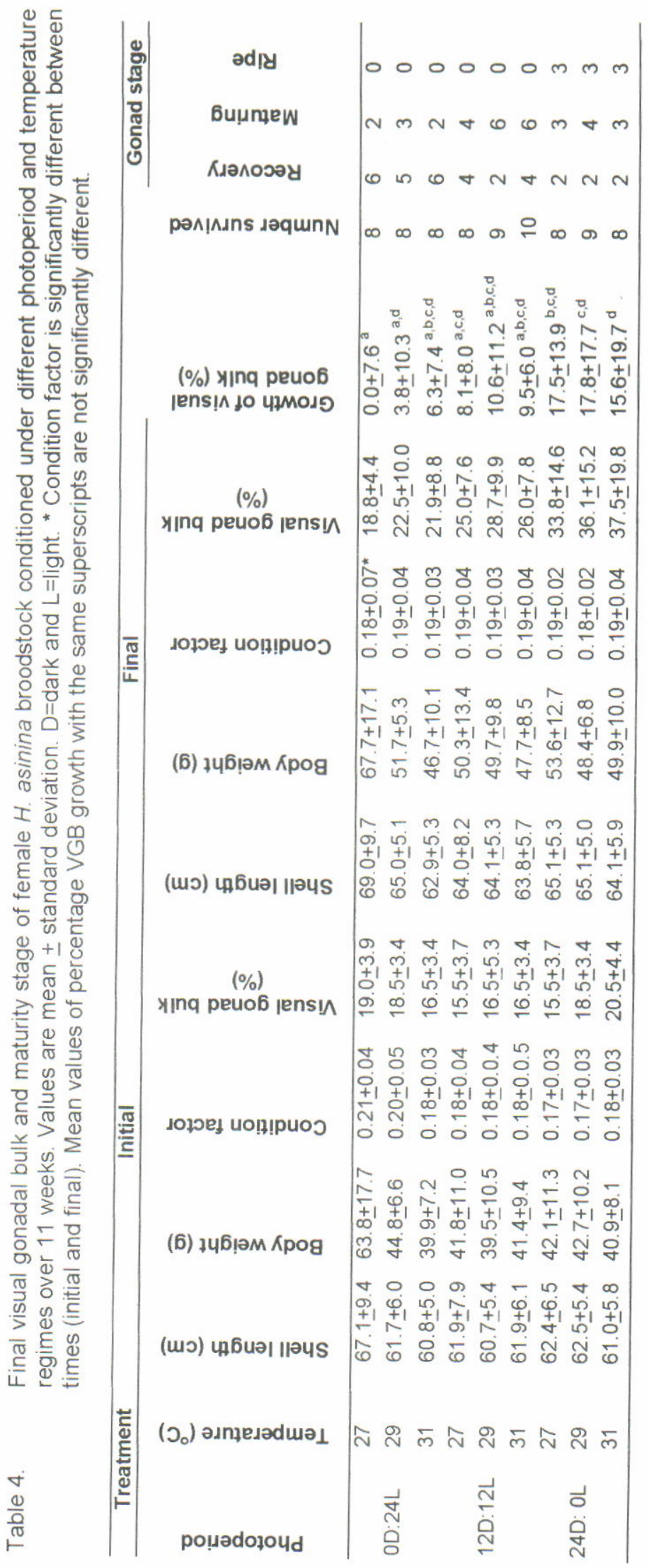




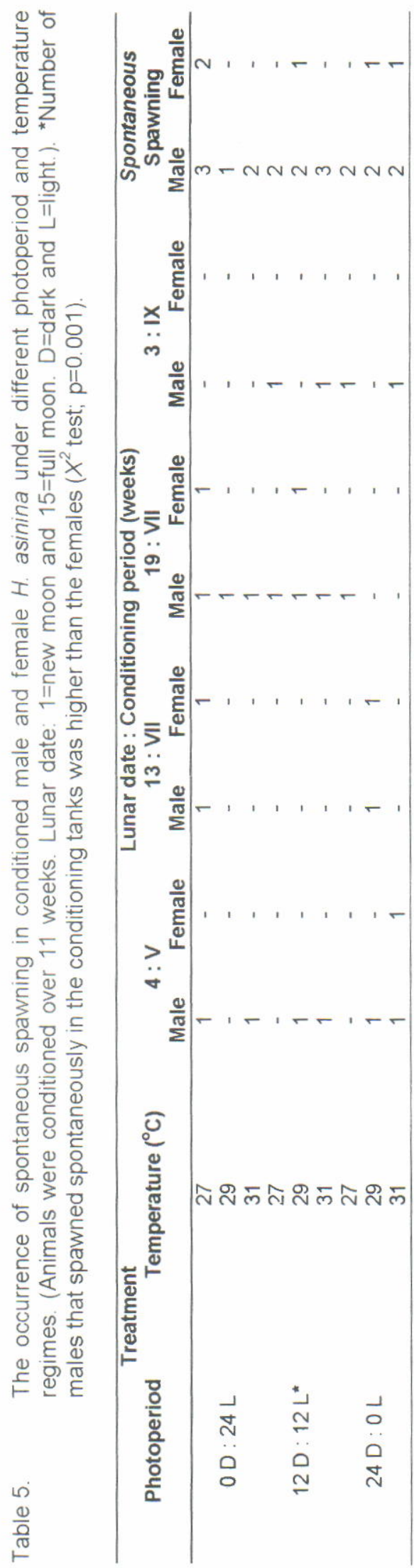


need to spawn first and thus stimulate females to release their gametes. Observations done by Capinpin et al., (1998) \& Setyono (2003) suggest that males begin releasing their gametes slightly earlier than the females.

Compared to the males, female broodstock showed a wide range of gonad growth at different photoperiod and temperature regimes. Visual gonadal bulk growth ranged about $0-6 \%$ at $0 D: 24 \mathrm{~L}, 8-11 \%$ at $12 \mathrm{D}: 12 \mathrm{~L}$, and $16-18 \%$ at $24 \mathrm{D}: \mathrm{OL}$. Some females conditioned under darkness for $24 \mathrm{hrs}$ became mature, and others fully mature (showing $>75 \%$ visual gonadal bulk). Some individuals even spawned spontaneously after being conditioned for 4 weeks (24D:OL at $\left.31^{\circ} \mathrm{C}\right), 6$ weeks (OD:24L at $27^{\circ} \mathrm{C}$ and $24 \mathrm{D}: \mathrm{OL}$ at $\left.29^{\circ} \mathrm{C}\right)$, and 8 weeks (12D:12L at $29^{\circ} \mathrm{C}$ ). These results show that photoperiod had a more significant effect on gonad growth in female $H$. asinina than the males. Reducing photoperiod may increase the rates of gonad maturation in females. Of course, light intensity should also be taken into account. However, because of limitations with equipment, this aspect was not examined in this study.

The results of the present study are in agreement with the outcome of a reproductive biology study on the wild population (Setyono, 2003). In the wild, the mean value of gonad indices increased sharply when sunshine-days (light intensity) started to decline (August-September) coinciding with the commencement of the rainy season in Lombok, when the sky was generally covered with clouds. During these months, animals with mature gonads dominated the population.

Success in gonad maturation under continuous darkness was achieved by Ebert \& Houk (1984) for red abalone, $H$. rufescens, although photoperiod did not act as a timer responsible for synchronisasion of reproductive development in this species. Some researchers are of the opinion that reducing photoperiod, even complete darkness, would facilitate and maximise feeding rates (abalone are nocturnal and actively feed at night) and shorten the time required to condition (Clarke \& Creese, 1988; Moss, 1998).

The occurrence of spontaneous spawning and the range of gonad maturation stages observed in the present study indicate that gonad development was individually regulated by other factors besides water temperature and photoperiod. Individual feeding rate and endogenous (hormonal) factors are suggested to have played a role in controlling gonad maturation in $H$. asinina. Fleming (1999) stated that both quantity and quality of food ingested by abalone influence not only gonad development but also gamete release. Moreover Fleming (1999) reported that the nutritional influence is greater in females than in males.
Unfortunately a lack of suitable facilities did not allow endogenous factors to be examined in the present study.

Hahn (1989b) suggested that rearing tanks used for conditioning must not cause any stress to the adult animals during the process. In this study, animals were handled carefully and all laboratory work (water changes and food) was carried out with the minimum of disturbance. The size of the tank was not considered to be a limitation as Ebert and Houk (1984) have conditioned $H$. rufescens in a 15 litre polyethylene plastic containers with no problems.

\section{ACKNOWLEDGMENTS}

I would like to thank and show my appreciation to the Head, staff and technicians of 'Loka Budidaya Lombok' for the support, help, and good collaboration during the study. A Special big thanks to Ir. Bambang Budi Raharjo, Yayan Sofyan, Bagja, Narti, Sukre, Ade and Luluk for their courtesy, love, and hospitality while I was doing the study in Gerupuk, Lombok, NTB.

\section{REFERENCES}

Barkai, R \& Griffiths, C. L. 1988. An energy budget for the south African abalone Haliotis midae Linnaeus. Journal of Molluscan Studies, 54: 43-51.

Bohlken, S. \& Joosse, J. 1982. The effect of photoperiod on female reproductive activity and growth of pulmonate snail, Lymnaea stagnalis, kept in laboratory breeding conditions. International Journal of Invertebrate Reproduction, 4: 213-222.

Bohlken, S., Joosse, J., \& Geraerts, W.P.M. 1987. Interaction of photoperiod, grouping and isolation in female reproduction of Lymnaea stagnalis, kept in laboratory breeding conditions. International Journal of Invertebrate Reproduction and Development, 11: 45-58.

Capinpin, Jr. E.C., Encena II, V.C., \& Bayona, N.C. 1998. Studies on the reproductive biology of the Donkey's ear abalone Haliotis asinina in Linne. Aquaculture, 166: 141-150.

Chua, T.E. \& S.K. Teng, 1978. Effects of feeding frequency on the growth of young estuary grouper, Epinephelus tauvina (Forskal), cultured in floating net-cages. Aquaculture, 14: 31-47.

Clarke, C.B. \& Creese, R.G. 1988. On-growing cultured abalone (Haliotis iris) in northern New Zealand. Journal of Shellfish Research, 17: 607613. 
Dogterom, G.E., Bohlken, S., \& Joosse, J. 1983. The effect of the photoperiod on the time schedule of egg-mass production in Lymnaea stagnalis, induced by ovulation hormone injection. General Comparative Endocrinology, 49: 255-260.

Ebert, E.E. \& Houk, J.L. 1984. Elements and innovations in the cultivation of red abalone, Haliotis rufescens. Aquaculture, 39: 375-392.

Fleming, A.E. 1999. Conditioning Australian abalone broodstock: best practice manual. A report for the Marine Research Institute, Queenscliff, Victoria, Australia, $34 \mathrm{pp}$.

Grange, K.R. 1976. Rough water as spawning stimulus in some trochid and turbinid gastropods. New Zealand Journal of Marine and Freshwater Research, 10: 203-216.

Hahn, K.O. 1989a. Gonad reproductive cycles. In: Handbook of culture of abalone and other marine gastropods (Hahn, K.O. ed.). CRC Press, Inc. Boca Raton, Florida, p. 13-40

Hahn, K.O. 1989b. Artificial induction of conditioning (gonad maturation). In: Handbook of culture of abalone and other marine gastropods ( Hahn, K. O. ed.). CRC Press, Inc. Boca Raton, Florida, p. 41 52

Hahn, K.O. 1989c. Artificial induction of spawning and fertilization. In: Handbook of culture of abalone and other marine gastropods (Hahn, K.O. ed.). CRC Press, Inc. Boca Ratoh, Florida, p. 53-70.

Ikenoue, $H$ \& Kafuku, T. 1992. Modern method of aquaculture in Japan. Development in aquaculture and fisheries science, vol. 24. Kodansha Ltd, Tokyo, p. 206-216.

Kabir, N.M.J. 2001. Environmental, chemical, and hormonal regulation of reproduction in two commercially important New Zealand abalone, Haliotis iris and $H$. australis. Unpublished PhD thesis. University of Otago, Dunedin, New Zealand, $236 \mathrm{pp}$

Kinne, O. 1970. Temperature. In: "Marine ecology. A comprehensive integrated treatise on life in ocean and coastal waters". (Kinne, O. ed). Vol. 1. Wileyinterscience, London, p. 407-514.

Lasiak, T. 1987. The reproductive cycles of three trochid gastropods from the Transkei Coast, Southern Africa. Journal of Molluscan Studies, 53 . 24-32.

Lundelius, J.W. \& Freeman, G. 1986. A photoperiod gene regulates vitellogenesis in Lymnaea peregra
(Mollusca: Gastropoda: Pulmonata). International Journal of Invertebrate Reproduction and Development, 10: 201-226.

Mc Crone, E.J. \& Sokolove, P.G. 1979. Brain-gonad axis and photoperiodically-stimulated sexual maturation in the slug, Limax maximus. Journal of Comparative Physiology, 133: 117-123.

Moss, G.A. 1998. Yellowfoot paua-A candidate for farming. Seafood New Zealand, June 1998, p. 2830

Runham, N.W. 1988. Mollusca. In: Reproductive biology of invertebrates. Vol. III. Accessory sex glands. (Adiyodi, K. G. \& Adiyodi, R. G. eds.). John Wiley \& sons, New York, p. 113-188.

Saout, C., Quere, C., Donval, A., Paulet, Y-M., \& Samain, J-F. 1999. An experimental study of the combined effect of temperature and photoperiod on reproductive physiology of Pecten maximus from the Bay of Brest (France). Aquaculture, 174 301-314.

Setyono, D.E.D. 2003. Reproductive biology and seed production techniques for tropical abalone (Haliotis asinina L.) in eastern Indonesia. Unpublished PhD thesis. University of Otago, Dunedin, New Zealand, 274 pp

Shepherd, S.A. \& Laws, H.M. 1974. Studies on Southern Australian abalone (Genus Haliotis). I. Reproduction of five species. Australian Journal Marine and Freshwater Research, 25: 217-257.

Tutschulte, T. \& Connell, J.H. 1981. Reproductive biology of three species of abalones (Haliotis) in Southern California. The Veliger, 23: 195-206.

Underwood, A.J. 1974. The reproductive cycles and geographical distribution of some common eastern Australian prosobranchs (Mollusca: Gastropoda). Australian Journal of Marine and Freshwater Research, 25: 63-88.

Wayne, N.L. \& Block, G.D. 1992. Effect of photoperiod and temperature on egg-laying behaviour in marine mollusk, Aplysia californica. Biology Bulletin, 182: 8-14

Webber, H.H. 1977. Gastropoda: Prosobranchia. In: Reproduction of marine invertebrates. Vol. IV (Giese, A. C. \& Pearse, J. S. eds.). Academic Press, New York, p. 1-98.

Wells, F.E. \& Keesing, J.K. 1989. Reproduction and feeding in the abalone Haliotis roei Gray. ) Australian Journal of Marine and Freshwater Research, 40: 187-197 